\title{
CALL Gene Is Haploinsufficient in a 3p- Syndrome Patient
}

\author{
Debora Angeloni, ${ }^{1 *}$ Noralane M. Lindor, ${ }^{2}$ Svetlana Pack, ${ }^{3}$ Farida Latif, ${ }^{1}$ Ming-Hui Wei, ${ }^{1}$ and \\ Michael I. Lerman ${ }^{1}$ \\ ${ }^{1}$ Laboratory of Immunobiology, National Cancer Institute, Frederick Cancer Research and Development Center, \\ Frederick, Maryland \\ ${ }^{2}$ Department of Medical Genetics, Mayo Clinic, Rochester, Minnesota \\ ${ }^{3}$ Laboratory of Pathology, National Cancer Institute, National Institutes of Health, Bethesda, Maryland
}

\begin{abstract}
The 3p- syndrome results from deletion of a terminal segment of the short arm of one chromosome $3(3 \mathrm{p} 25 \rightarrow$ pter $)$, and is characterized by multiple congenital anomalies and mental retardation. Due to its variable expression, it is assumed this disorder is a contiguous gene syndrome with an undefined number of genes contributing to the phenotype. In an effort to discover genes contributing to mental defects in 3p- syndrome, we determined whether the CALL gene, mapped to $3 p 26.1$ and coding for a neural recognition molecule, is deleted in a boy with this disorder. We found that the break in this patient is distal to the VHL gene, removing D3S18 and the CALL loci. The deletion of one copy of the CALL gene might be responsible for mental defects in patients with 3p-syndrome. Am. J. Med. Genet. 86:482-485, 1999.

Published 1999 Wiley-Liss, Inc. ${ }^{\dagger}$
\end{abstract}

\section{KEY WORDS: CALL; 3p- syndrome; IQ}

\section{INTRODUCTION}

Distal deletions of the short arm of chromosome 3 cause a condition referred to as the $3 \mathrm{p}-$ syndrome [Verjaal and De Nef, 1978]. With variable morbidity, that may reflect differences in the deletion size, the $3 p-$

Contract grant sponsor: National Cancer Institute, National Institutes of Health; Contract grant number: NO1-CO-56000.

The content of this publication does not necessarily reflect the views or policies of the Department of Health and Human Services, nor does mention of trade names, commercial products, or organizations imply endorsement by the U.S. Government.

*Correspondence to: Debora Angeloni, Laboratory of Immunobiology, National Cancer Institute, Frederick Cancer Research and Development Center, Building 560, Room 12-68, Frederick, MD 21702-1201. E-mail: andreazzolid@mail.ncifcrf.gov

Received 8 March 1999; Accepted 10 June 1999

Published 1999 Wiley-Liss, Inc. †This article is a US Government work and, as such, is in the public domain in the United States of America. syndrome includes low birth weight and growth failure, mental and psychomotor retardation, microcephaly, triangular face, synophrys, blepharoptosis, hypertelorism, broad and flat nose, long philtrum, downturned mouth, cleft palate, micrognathia, low-set and malformed ears, finger abnormalities, and deafness. Renal anomalies, gastrointestinal anomalies, and congenital heart defects may also be present [Drumheller et al., 1996]. Cytogenetic analyses have defined the deletion breakpoints at 3p25-3p26, virtually identical in all cases reported [Nienhaus et al., 1992; Asai et al., 1992; Narahara et al., 1990]. Only two genes have been mapped at this region. The ATP2B2 gene [Latif et al., 1993a], that maps between D3S1585 and D3S1317, was considered a candidate for the congenital heart malformations [Phipps et al., 1994]. VHL [Latif et al., 1993b], another gene in this region telomeric to the ATP2B2 locus, was shown to be either retained or deleted in different patients, exposing the latter group to risk of developing Von Hippel-Lindau disease. No candidate genes have been identified to explain general growth failure or mental impairment, constant findings in the $3 p-$ syndrome. Recently the CALL gene was cloned [Wei et al., 1998]. CALL maps at 3p26.1 and codes for a novel member of the L1 gene family of neural cell adhesion molecules. In this study we show that CALL is deleted in a male patient with $3 \mathrm{p}-$ syndrome. Due to the possible role of the gene in the development and function of the brain, we suggest that CALL is a gene whose haploinsufficiency is responsible for some mental impairment characteristic of patients with $3 p-$ syndrome.

\section{MATERIALS AND METHODS}

\section{Fluorescent In Situ Hybridization (FISH)}

Metaphase spreads derived from 5-bromo-deoxyuridine synchronized peripheral lymphocytes of the $3 p-$ syndrome patient were used as a template. Probes were labeled with digoxigenin 11-dUTP by nick translation and hybridization signals were detected with rhodamine-conjugated anti-digoxigenin antibodies (Boehringer Mannheim). The condition of hybridization, detection of hybridization signals, and digital im- 
age acquisition, processing, and analysis were performed as described previously [Pack et al., 1997]. Chromosomes were identified by converting DAPI banding into G-simulated banding using the IP Lab Image Software (Scan Analytics Corp.). Rehybridization with alpha-satellite centromeric probe (Oncor) specific for chromosome 3 was performed to confirm chromosomal localization.

\section{Southern Blot}

Ten micrograms of genomic DNA were digested with restriction enzyme TaqI, according to the manufacturers' specification (GIBCO-BRL, Gaithersburg MD; Boehringer Mannheim, Indianapolis IN) in buffers supplemented with $5 \mathrm{mM}$ spermidine. Digested DNA was run on $1 \%$ agarose gel, alkaline denatured, transferred to nylon membranes (Hybond $\mathrm{N}+$, Amersham, Arlington Heights, IL) and fixed by UV baking, according to the manufacturer's specification (UV Stratalinker, Stratagene, La Jolla, CA). Radioactive DNA probe (L162 band $5.5 \mathrm{~kb}$ ) was prepared by random priming (Rediprime II, Amersham). The filters were washed stringently $\left(60-65^{\circ} \mathrm{C}, 0.1 \times \mathrm{SSC}\right.$ buffer, $1 \%$ SDS) and exposed to X-OMAT AR film (Eastman Kodak, Rochester, NY) with double intensifying screen (Dupont Chemical, Wilmington, DE) at $-80^{\circ} \mathrm{C}$.

\section{CLINICAL REPORT}

The propositus was a boy almost 12 years old, referred for generalized weakness. He was born at term after an uneventful, planned pregnancy. He was delivered by Cesarean section due to breech presentation. Birth weight was 3,450 g. Moderate hyperbilirubinemia was treated with phototherapy. A heart murmur resolved in infancy. He had glandular hypospadias. He had no apparent bowel or renal problems and no herniae. He had a recurring rash over both cheeks not related to sun exposures and rough skin over his forearms. He has been in speech therapy because of deficient soft palatal movement that affected the quality of his speech. He had no respiratory illnesses of consequence. Hearing tests indicated conductive hearing loss in the left ear. He wore glasses for myopia. He gained weight well through the third or fourth month of his life, and was at the 90th centile for height and weight. Thereafter, his weight gain decelerated, and by age 8 to 12 months he was gaining inadequately. Psychomotor development was delayed: he sat at 8 months, crawled at 11 months, and walked at age 2 years. His first word was said at 2.5 years. From the age of 18 months he was in a preschool program for developmentally delayed children. His major problem was generalized fatigability and weakness. He had difficulty with fine motor coordination, including buttoning clothing, using eating utensils, and writing. He had not had difficulty with choking or swallowing. A preschool evaluation demonstrated delays in gross and fine motor areas. The adjusted IQ (1989) was 81. Results of the academic achievement test (at age 9) were as follows: math application 19th centile, math computation 5 th centile, reading decoding 23 rd centile, reading comprehension 21 st centile, spelling 5 th centile.
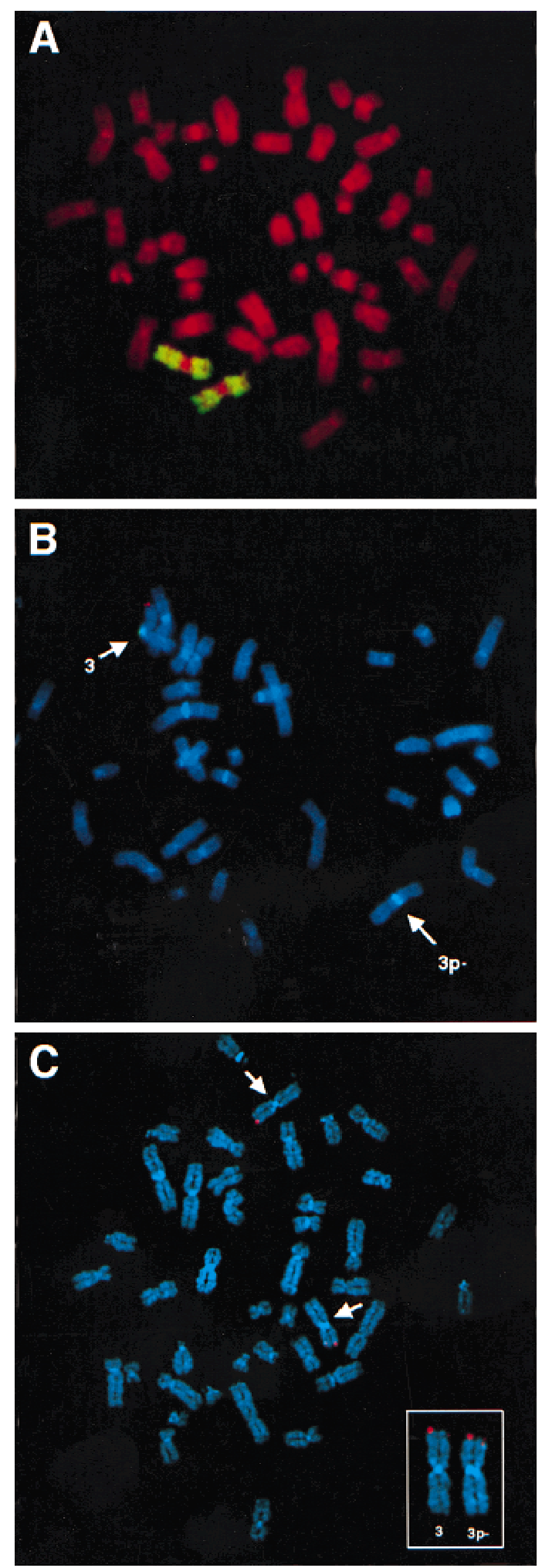

Fig. 1. Fluorescent in situ hybridization on metaphase spreads of the propositus. A: Coatosome 3 staining shows no detectable translocation of chromosome 3 regions to other chromosomes. B: A CALL gene probe (7.6$\mathrm{kb}$ cDNA) reveals only one copy of the gene (red spot). C: A VHL gene probe (P1-clone) detects a diploid complement of the gene (red spots, see inset). White arrows in $\mathrm{B}$ and $\mathrm{C}$ indicate chromosomes 3 centromeres identified by alpha-satellite centromeric probe (Oncor). 

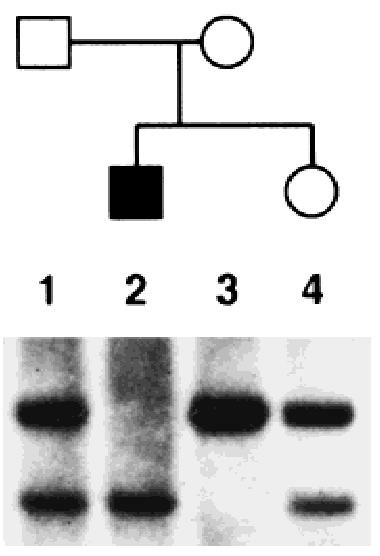

Fig. 2. RFLP analysis of D3S18 locus with L162 probe [Tory et al., 1992]. The pedigree above represents the propositus' family. His father is heterozygous for a TaqI polymorphic site (lane 1); his mother is homozygous for the allele 2 (lane 3). His sister inherited allele 1 from the father and allele 2 from the mother (lane 4). The propositus (lane 2) inherited the allele 1 from his father; the maternal allele was lost.

On physical examination at age 12 , he was a slender, mildly unusual-appearing preadolescent boy. His height was $132 \mathrm{~cm}$ (<5th centile), weight $21.5 \mathrm{~kg}$ (far $<5$ th centile). The head was normocephalic, with normal hairline. There was mild hypertelorism with slightly downslanting right palpebral fissure; nose was unremarkable; the philtrum was well formed and not elongated. The palate was somewhat highly arched, without clefting. The helices were both $\mathrm{C}$ shaped; the right was markedly overfolded superiorly and the left superior helix was unfolded and had a serrated edge. The limbs were thin, with hyperextensibility at elbows, wrists, fingers, and knees. He has no digital abnormalities. Hand palms are long and narrow, with bilateral sydney lines. Each index finger has a low arch. Other-

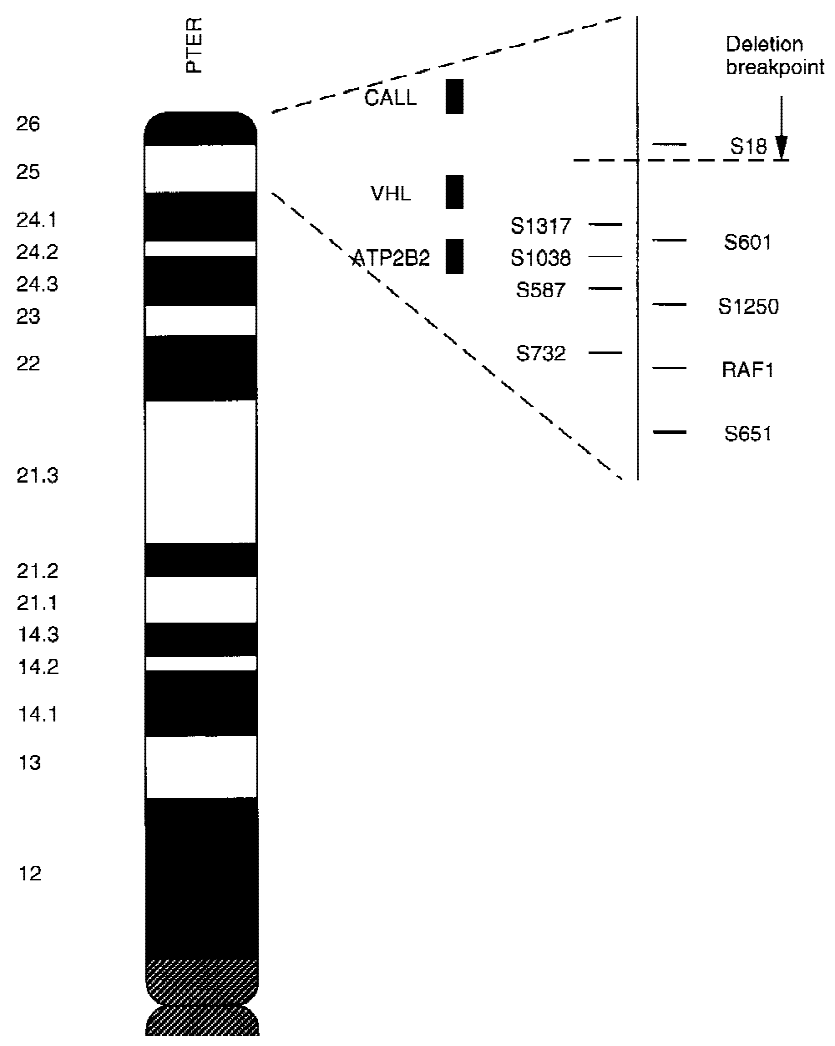

Fig. 3. Map of chromosome 3p. The reciprocal position of markers in 3 p25 3p26, discussed in the text, is shown.

wise, a combination of whorls and loops were the noted dermatoglyphics. A neurological examination showed decreased strength in all muscle groups, with slow and deliberate movement without ataxia. Deep tendon reflexes were faintly present at the biceps, quadriceps, and ankles.

\section{Cytogenetic and Molecular Studies}

His karyotype was 46, XY, $\operatorname{del}(3)(\mathrm{p} 25.3)$ de novo. A coatosome 3 painting showed no detectable translocations (Fig. 1A). A FISH experiment performed with the CALL cDNA probe showed a hemizygous deletion of the gene (Fig. 1B). Using a large P1 clone, the patient was screened by FISH for a possible deletion of the VHL gene and was found to have retained both copies (Fig. 1C), excluding future complications related to the Von Hippel-Lindau syndrome. Finally, a restriction fragment length polymorphism (RFLP) analysis of the D3S18 locus was performed and showed deletion of this marker (Fig. 2), placing the breakpoint between VHL and D3S18 (Fig. 3).

\section{DISCUSSION}

The characteristics of the $3 p$ - syndrome are well known. Several molecular markers were studied recently to analyze the relationship between phenotypic traits and marker deletions [Drumheller et al., 1996]. Unfortunately, very few genes have been mapped so far in the region affected by the deletion. One known gene codes for the plasma membrane calcium transporting ATPase (ATP2B2) [Latif et al., 1993a], and represents a plausible candidate for the congenital heart defects described in several 3p-syndrome patients. Recently, the attempt to identify genes possibly involved in mental impairment in the 3p- syndrome led to the discovery of the CALL gene, located at chromosome region 3p26.1, coding for a novel member of the L1 gene family of neural cell recognition molecules [Wei et al., 1998]. These proteins play an important role in the building and functioning of the brain, because many events, such as cell migration, axonal growth, fasciculation, synaptogenesis, and synaptic remodeling, all require cell-to-cell and cell-to-matrix interactions. In fact, mutations in the L1 gene are associated with a broad range of neurological disorders [Bateman et al., 1996; Fransen et al., 1997]. Cell adhesion and cell recognition molecules are expressed also during heart development. In addition to the contractile proteins, some of the early expressed genes in the heart are coexpressed with neuroectodermal or neuroendocrine tissues (e.g., ANP, CAM, GIN, etc.) [Thorogood, 1997; p. 359].

Our work is the first in which a gene coding for a neural recognition molecule mapping at 3 p26.1 is shown to be hemizygous in a male patient with $3 p-$ syndrome, characterized by mental impairment. The problem of gene dose probably is crucial in the context of the $3 p-$ syndrome. It is likely that hemizygosity of genes in the minimal critical region leads to insufficient gene product(s) of some growth or developmental regulators. Several syndromes are described [Dallapiccola et al., 1995] caused by a gene dosage deficit. It is more and more accepted that highly regulated pat- 
terns of gene expression in developing organisms are affected by stochastic processes, and, recently, a model was proposed to study the implications of stochastic gene expression in causing haploinsufficiency [Cook et al., 1998]. The authors suggested that null mutations of a single allele in a diploid organism could decrease the probability of gene expression, so that some haploinsufficiency syndromes might result from an increased susceptibility to stochastic delays of initiation or interruption in gene expression.

Since both maternal and paternal deletions are described, the $3 p-$ syndrome is not likely influenced by genomic imprinting events [Mowrey et al., 1993].

Other $3 \mathrm{p}$ - patients studied at the molecular level [Mowrey et al., 1993; Phipps et al., 1994; Drumheller et al., 1996], showed terminal deletions, with breakpoints within 3p25.3. It is reasonable to assume that they underwent the CALL gene deletion. All these patients had mental retardation.

Further studies are necessary to evaluate the extent of the CALL gene haploinsufficiency in determining the mental developmental abnormality typically associated with the $3 \mathrm{p}-$ syndrome.

\section{REFERENCES}

Asai M, Ito Y, Iguchi T, Ito J, Okada N, Oishi H. 1992. Terminal deletion of the short arm of chromosome 3. Jpn J Hum Genet 37:163-168.

Bateman A, Jouet M, MacFarlane J, Du JS, Kenwrick S, Chothia C. 1996. Outline structure of the human L1 cell adhesion molecule and the sites where mutations cause neurological disorders. EMBO J 15:6050-6059.

Cook DL, Gerber AN, Tapscott SJ. 1998. Modeling stochastic gene expression: Implications for haploinsufficiency. Proc Natl Acad Sci USA 95: 15641-15646.

Dallapiccola B, Mingarelli R, Novelli G. 1995. The link between cytogenetics and mendelism. Biomed Pharmacother 49:83-93.

Drumheller T, McGillivray BC, Behrner D, MacLeod P, McFadden DE, Roberson J, Venditti C, Chorney K, Chorney M, Smith DI. 1996. Precise localisation of 3 p25 breakpoints in four patients with the $3 p-$ syndrome. J Med Genet 33:842-847.
Fransen E, Van Comp G, Vits L, Willems PJ. 1997. L1-associated diseases: Clinical geneticists divide, molecular geneticists unite. Hum Mol Genet 6:1625-1632.

Latif F, Duh FM, Gnarra J, Tory K, Kuzmin I, Yao M, Stackhouse T, Modi W, Geil L, Schmidt L, Li H, Orcutt ML, Maher E, Richards F, Phipps M, Ferguson-Smith M, Le Paslier D, Linehan WM Zbar B, Lerman MI. 1993a. Von Hippel-Lindau syndrome: Cloning and identification of the plasma membrane $\mathrm{Ca}(++)$-transporting ATPase isoform 2 gene that resides in the Von Hippel-Lindau gene region. Cancer Res 53:861-867.

Latif F, Tory K, Gnarra J, Yao M, Duh FM, Orcutt ML, Stackhouse T, Kuzmin I, Modi W, Geil L, Schmidt L, Zhou F, Li H, Wei MH, Chen F, Glenn G, Choyke P, Walther MCM, Weng Y, Duan DSR, Dean M, Glavac D, Richards F, Crossey PA, Refguson-Smith MA, Le Paslier D, Chumakov I, Cohen D, Chinault C, Maher ER, Linehan WM, Zbar B, Lerman MI. 1993b. Identification of the Von Hippel-Lindau disease tumor suppressor gene. Science 260:1317-1320.

Mowrey PN, Chorney MJ, Venditti CP, Latif F, Modi WS, Lerman MI, Zbar B, Robins DB, Rogan PK, Ladda RL. 1993. Clinical and molecular analyses of deletion 3p25-pter syndrome. Am J Med Genet 46:623-629.

Narahara K, Kikkawa K, Murakami M, Hiramoto K, Namba H, Tsuji K, Yokoyama Y, Kimoto H. 1990. Loss of the 3p25.3 band is critical in the manifestation of del(3p) syndrome: Karyotype-phenotype correlation in cases with deficiency of the distal portion of the short arm of chromosome 3. Am J Med Genet 35:269-273.

Nienhaus H, Mau U, Zang KD. 1992. Infant with del(3) (p25-pter): Karyotype-phenotype correlation and review of previously reported cases. Am J Med Genet 44:573-575.

Pack SD, Tanigami A, Ledbetter DH, Sato T, Fukuda MN. 1997. Assignment of trophoblast/endometrial epithelium cell adhesion molecule trophinin gene TRO to human chromosome bands Xp11.22 $\rightarrow$ p11.21 by in situ hybridization. Cytogenet Cell Genet 79:123-124.

Phipps ME, Latif F, Prowse A, Payne SJ, Dietz-Band J, Leversha M, Affara NA, Moore AT, Tolmie J, Schinzel A, Lerman MI, Ferguson-Smith MA, Maher ER. 1994. Molecular genetic analysis of the 3p- syndrome. Hum Mol Genet 3:903-908.

Thorogood P, editor. 1997. Embryos, genes and birth defects. New York: Wiley.

Tory K, Latif F, Modi W, Schmidt L, Wei MH, Li H, Cobler P, Orcutt ML, Delisio J, Geil L, Zbar B, Lerman MI. 1992. A genetic linkage map of 96 loci on the short arm of human chromosome 3. Genomics 13:275-286.

Verjaal M, De Nef MB. 1978. A patient with a partial deletion of the short arm of chromosome 3. Am J Dis Child 132:43-45.

Wei MH, Karavanova I, Ivanov SV, Popescu NC, Keck CL, Pack S, Eisen JA, Lerman MI. 1998. In silico-initiated cloning and molecular characterization of a novel human member of the L1 gene family of neural cell adhesion molecules. Hum Genet 103:355-364. 